\title{
Interferon Alpha Receptor Complex
}

National Cancer Institute

\section{Source}

National Cancer Institute. Interferon Alpha Receptor Complex. NCI Thesaurus. Code C37274.

Human Interferon Alpha Receptor Complex (Type II Cytokine Family Receptor) is a ubiquitous type I membrane protein heteromeric receptor for type I IFNs, alpha and beta, composed of at least 2 chains, IFNAR1 (alpha chain) and IFNAR2 (beta chain). In mediating innate immune responses to viral infection and specific interferon inhibition of virus replication, binding of alpha and beta IFNs triggers tyrosine phosphorylation of JAKs, TYK2, STAT proteins, autophosphorylation, and tyrosine phosphorylation by TYK2. (NCI) 